\title{
Symbolism In The Structure Of: Study Of Poetry "Retak Mencari Belah" By Junewal Muchtar
}

\author{
Tety Kurmalasari \\ \{ teti@umrah.ac.id \} \\ Faculty of Teacher Training and Education, Tanjungpinang, Kepri, 29111, Indonesia \\ Mobile: 081266238661
}

\begin{abstract}
The purpose of this study is to reveal about the symbols and meanings of the symbols contained in the poetry structure of Junewal Muchtar's poetry. The theory used in this research is symbol theory which analyzes an object representing a symbol. The method used in analyzing this poem is descriptive and qualitative methods. The source of the data was obtained from the collection of poetry Retak Looking for Belah by Jenewal Mucthar. The results of this study indicate that the symbols contained in 46 poems by Jenewal Muchtar are living things and objects. Symbols of living things include humans, animals and plants which have the meaning of piety, faith, honor, power, loyalty, stength, peace and so on. as well as objects including anchors, bottles, glasses, and others which have the meaning of being transparent, and easily cracked.
\end{abstract}

Keywords: Symbolism, Poetry, Structure

\section{Introduction}

\subsection{Background Of The Study}

Basically, poetry is an expression of emotion. Poetry usually appears in the form of sections (paragraphs) and chapters in several kinds of structures such as parables, allegory and figurative language. Poetry is a literary work in the form of responses and opinions of poets on various things [6]. This thought is then embodied by using beautiful languages and having an inner and physical structure as a characteristic [12]. Based on the scale, the form of poetry can be said as a literary work to convey all aspects of life deeply and broadly with far fewer words than other literary works. There are two types of poetry, namely old poetry and modern poetry. Old poetry can be in the form of rhymes, talibun, mantra, and gurindam [2]. Modern poetry can be in the form of narrative poetry, lyric poetry, and descriptive poetry. Modern poetry is usually called free poetry because it is not constrained by rhyme, number of lines, and so on. There are several ways to write poetry. The first stage is to create a framework, starting from determining the type of poetry. If the reader wants to write old poetry, then the rhythm and rhyme must be determined in advance so that the message to be conveyed can be understood. The second stage is to determine the title to make it easier to limit the expression of emotion to be conveyed through poetry. The third stage is the creative process by reading references or imagining. Literature is an expression of thoughts, feelings, ideas, and beliefs in the form of words, pictures, and actions [9]. Literary works can be in the form of imaginative literary works with the aim of explaining, explaining, understanding, opening new views, and giving meaning to the reality of life so that humans better understand and behave properly in the reality of life, in addition, there are non-imaginative literary works with the aim of showing facts that tend to use denotative and fixed expressions. 


\subsection{Problem Formulation}

Based on the background above, how are the symbols in the structure of "Retak Mencari Belah" poetry by Junewal Muchtar?

\subsection{Purpose}

This study aimed to analyze the symbols in the structure of "Retak Mencari Belah" poetry by Junewal Muchtar?

\section{Method}

This study was carried out using descriptive and qualitative methods. Qualitative descriptive methods merely describe facts or language phenomena empirically as in reality. Thus, it is hoped that the data will show the situation as it is [5], [8].

This study used library techniques and note-taking techniques. The library technique is a method of collecting data in the form of goods or written objects [10]. Such as "Retak Mencari Belah" poetry by Junewal Muchtar [11].

The note-taking technique is a method of collecting data by reading, taking notes, and understanding theories related to the problem required by quoting directly and indirectly and then reflecting on it.

Poetry is a work of art with a special meaning of beauty. Poetry as a work of literary art can be studied from two main elements, both of which consist of elements that bind each other and all of these elements form a whole meaning given that poetry is a structure composed of various poems. Poetry consists of solid building elements because they cannot be separated without relating other elements [7].

\section{Literature Review}

Poetry is a form of literary work using beautiful and meaningful words [3]. Poetry is a literary work in the form of responses and opinions of poets on various things. This thought is then embodied by using beautiful languages and having an inner and physical structure as a characteristic. According to Burke in Setiawan, works of art, including literature, "are strategic namings of situations" so that readers can better understand and "control" social events through works of art [13].

In Poetry there are two elements, namely intrinsic elements an extrinsic elements [12]. There are seven Intrinsic Elements of Poetry, namely:

\section{a. Theme}

Theme is the main idea or idea of poetry. Every poetry has many things to discuss, but must have one main topic of discussion. The main topic is called the theme.

b. Feeling

Feeling shows the thoughts and feelings of the poet that are able to influence the reader or listener after reading or hearing poetry. Feelings can be happy, sad, touched, and so on. The more conveyed the feeling to the reader or listener, the better the poetry will be. 


\section{c. Imagery}

Imagery is an image generated when reading poetry. Imagery touches the reader or listener through hearing, sight, touch, and others. Imagery aims to make the reader or listener able to understand and really understand the meaning of the poetry. Imagery is usually categorized as follows: sight, hearing, touch, smell, taste, movement, feeling, and intellectual.

\section{d. Symbol}

The symbol is an element showing that the words in poetry have other meanings and purposes. For example "Heart is Made of Steel", the word "Steel" can symbolize the strength that is hard to break.

e. Tone

Poetry is composed of certain words with meaning and is also beautiful to hear. These words serve the overall meaning in poetry. The tone in question is the arrangement of words that are meaningful, beautiful, and also interesting to hear the sound so that it is interesting for the reader or listener.

\section{f. Language style}

The basis of a poetry structure is language. Each poet has a different language style, this language style is the choice according to the thoughts and feelings when making the poetry. There are several things that cause differences in the choice of words in poetry, including differences in times, life experiences, cultural differences and others.

g. Message

Every poetry has a certain meaning, after understanding the theme, meaning, and sound in the poetry. The message in a poetry is usually conveyed implicitly, so the reader must really understand the poetry correctly in order to get the message

Extrinsic Elements of Poetry

Extrinsic elements are not directly related to poetry, namely:

a. Social conditions of the poet

b. Neighborhood of poet

c. Profession of poet

d. Experience of poet

e. Economic conditions of the poet

f. The role of the poet in society

Symbols denote or represent and give the impression of something else. For example, the dove is a symbol of peace [5]. A symbol is a sign that can be seen and can be replaced with an idea or object. Symbols are usually interpreted in a limited way as a traditional symbol or something constructed by the community or individual with a certain meaning. Symbols can be in the form of many things that are considered to give meaning to literary works. Symbols can explain an event based on imagination.

In traditional literary usage, symbols connect words or thoughts with certain objects, scenes, or actions, althought they are fundamentally different, they have certain semantic relationships [13].

According Martin, B. \& Felizitas, R in Setiawan, In Peirce's semiotics, the term symbol denotes a sign (signifier) whose relationship to its object (signified) is entirely arbitrary or based on convention. An example would be the word 'car' where there is no causal physical link or resemblance between the sign (the word car) and its object. In his 
system of classification, Peirce distinguishes signs used as symbols from those used as icons or as indices [13].

According to Finkelstein in Setiawan, There are three kinds of symbol, they are: Archetypal symbols, conventional symbol and personal symbol. Archetypal symbols are the universal roles everyone must eventually play out in the act of consciousness integration [13].

\section{Result And Discussion}

\subsection{Symbolism in the poetry by Junewal Muchtar}

Symbols in the poetry by Jenewal Muchtar can be grouped into two elements namely living things and inanimate things. The symbols in the form of "living things" are humans, animals, and plants, while "inanimate things" are anchors, bottles, glasses, and others [1], [11].

\subsection{Sejenak di Bumi}

Poetry has a symbol of a person sitting in a back position with the meaning of gratitude, faith, and piety which means accepting God gifts wholeheartedly :

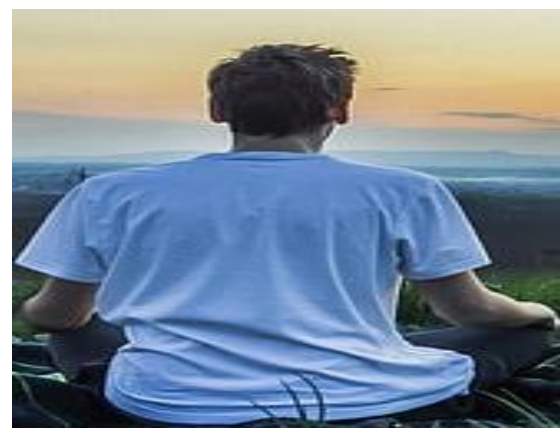

Fig 1. A Person sitting in a position

Kun katanya jadilah aku darinya

Maka berlayarlah

si anak muda itu

Dengan jalan pikirannya

jauh melangkah

Bahkan

sungai

gunung

ia daki

Dengan amarahnya

di bumi

Terkadang pikirannya

hanyut dimalam gelap

Lunglai 


\author{
jiwanya kian jadi hutan \\ Diapitnya sejuknya rimba \\ Walau hujan terus alirkan dendam \\ Pada kehidupan \\ si anak muda itu \\ Terus memaki-maki laut \\ Dengan siulan malam \\ Terkadang anak muda itu \\ Ingin sejenak lagi \\ menuai hidup \\ walau maut menjemput
}

\title{
4.1. 2 Tausiran Selamat Jalan
}

Poetry is symbolized by a tree showing strength and tranquility which means an atmosphere of peace, calm and physical ability.

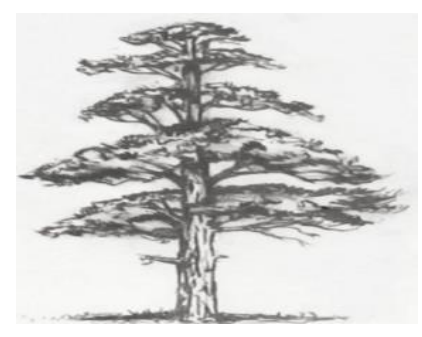

Fig 2. A Tree

Tak ada lagi kata yang buat aku tertawa

Apalagi reuni

yang lagi ngantor

dan Sibuk ngurusin negeri

Tak ada lagi suara hp yang mengajakku mncing

di air tenang

Yang ada kenangan

selembar proposal terakhir

Untuk mengabari dirinya

terserang penyakit jantung

Dan ia pergi

dengan kemarahan padaku

Tentang dirinya lelah

dan kaku

\subsection{Retak Mencari Belah}

Poetry is symbolized by bottle which has a closed meaning, rigid and cannot be changed. 


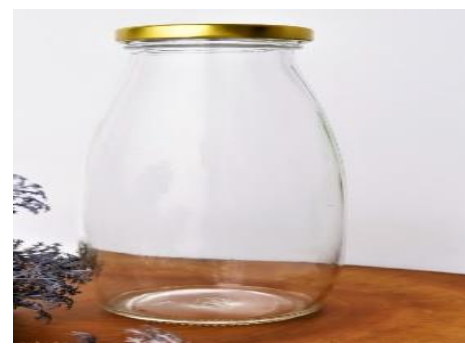

Fig 3. Bottle

Seorang penyair marah dan amuk dipucuk darahnya

Mengalirkan kata-kata sumpah dan caci maki

Kata penyair itu dengan nada dan bahasa

marahnya diterik matahari

Dimana-mana

kini tanah airku semakin retak jiwanya terombang-ambing dilaut gelap

Disana-sini tak harmonis antara kampung anu

Bertikai soal tanah yang digusur investor kapitalis

Antara penyair yang satu ini menulis puisi dicelana kolornya dengan kata-kata yang tak sedap Ah, tanah airku kini semakin retak dan porak poranda ada kalimat bait puisi

Caci maki tentang presiden merengek minta naik gaji belum kagi para anggota dewan Merampok uang negara dari hasil kongkalikong rupanya kalian wakil rakyat tukang bohongi rakyat puisi yang ditulis penyair itu sampai kemalaikat sampai ke tuhan

Ah, kalian telah buat negeri ini menjadi retak menjadi belah tanah air kami

Kalian jadikan lahan mencari uang dan kekayaan matahari terus menjalarkan perih Ke tubuh penyair yang lagi marah dan amuk itu 


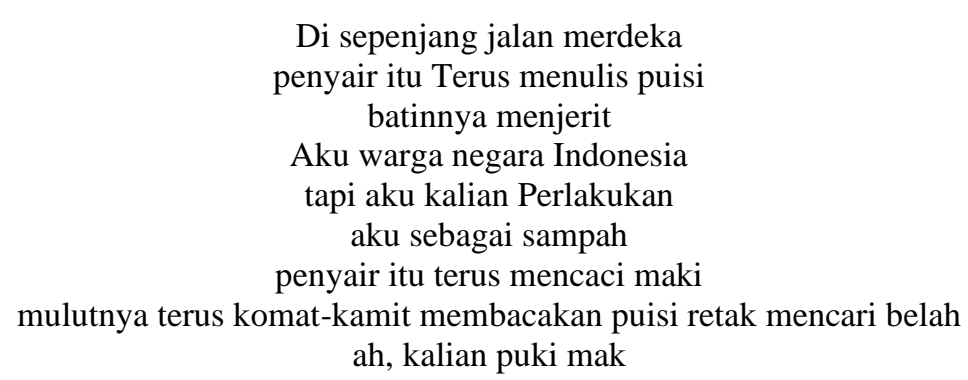

\subsection{Puisi Buat Anak dan Leluhur}

Poetry is symbolized glass which has a transparent meaning that is open to decisions.

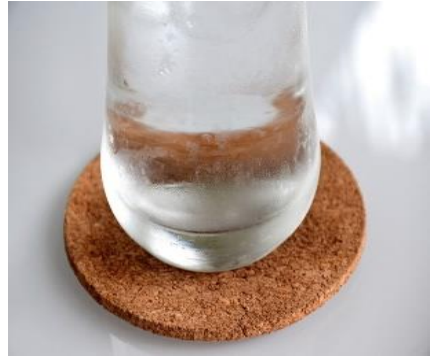

Fig 4. Glass

Tak ada yang ku berikan hanya ilmu dan agama yang kuberikan

Buat anak-anak dan leluhur

Jangan tanyakan tentang harta

Sejengkal tanah pun kita tak punya

hanya halaman puisi

tempat kita bersuka-suka

Apalgi sebongkah emas permata jangan kalian tanya nanti

Berangkatlah wahai anak-anakku juga cucuku

jadilah kalian api

penerang hidup dan bakar

Jiwa semangat kalian

agar kalian mampu belajar

Dengan kehidupan yang jujur dan beramanah

ini yang dapat ku berikan pada kalian

Anak-anakku juga cucuku

jangan takut jika benar

tantanglah kehidupan yang keras

Namun kalian pasti sampai 
berlayar ke tujuan asalmu

Ini wasiat puisi buat anakku

ikhasan, ega, puizi dan cucuku glen

Mari kita syairkan puisi

pada kancvas lukisan kehidupan

buat kita

\subsubsection{Di Tanjung Riau}

Poetry is symbolized by anchor that has the meaning of strength, namely immunity, resilience, toughness, skill, and etc.

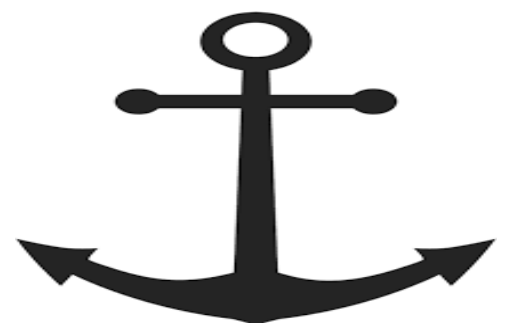

Fig 5. Anchor

Di tanjung riau

ada darah ngalirkan darah

di perahu malam

Berlayar diantara debar

kisah anak manusia

mengais bintang dan bulan

ditaman

Jam berdetak

tentukan nasib di liang

kubur tak bernama

Ada warkah tak terbaca

pada lembaran hati

melintas dipersimpangan gundah

Bocah-bocah berjalan kaki

dengan lumpur

keharuannya

Tak ada

berkas senyum kuntum

di tanjung riau

Tawanya membakar bocah-bocah

dengan batu karang dan bakau

kering diatas langit

Ditanjung riau 


\author{
para bocah tadahkan tangannya \\ dipersimpangan jalan raya \\ Antara perih dan luka \\ dihulu riau \\ para bocah menghitung nasibnya sekali lagi \\ Yang tak dapat menjamah \\ sepotong roti \\ ditanjung riau
}

\title{
4.1.3 Syair Engku Putri
}

Poetry is symbolized by centipede which has the meanings of strength and power, namely the ability to control the attitude of oneself and others directly or indirectly.

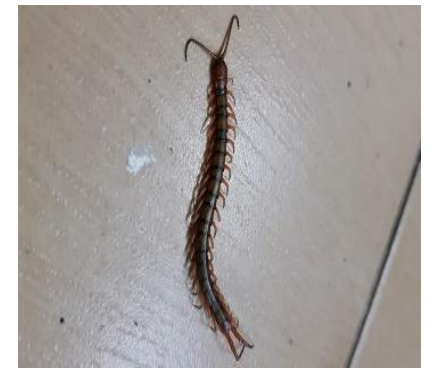

Fig 6. Centipedes

Adalah kisah yang pernah kugubah

dalam madal kehidupan

Ladang hati dan jiwaku membara

di selembar cogan

Yang kau jadikan kisah

seribu satu malam

pada pulau kahyangan

Yang bertuangkan putri sigunung

ledang

Kau jadikan aku si raja api

yang membakar diri kami kembali

Dari balik nisan yang mencakar

kehulu riau

Inilah syair engku putri

gurindam yang kugubah

Dengan sejuta

kata-kata

bermadahkan kekecewaan

pada sebuah pulau sejarah

Tak kurelakan cogan ini 
kau miliki,

walau cogan bertuah dan sakti

Tak lagi menjadi sakti dalam diri tuan

sebab telah

kusumpah seranahkan coganku

Tak jadikan kesaktian

dalam keinginan kalian

inilah syair engku putri

Yang tak pernah tuan kisahkan

dalam dendangan kisah

seribu satu malm

dipulau sejarah

Tuan tak pernah rasakan

debar dan gelisah syair engku putri

dalam sebait gurindam kutulis

di cogan sirih besar

yang menjadikan syair engku putri

bermarwah

\section{Conclusion}

Researchers find and classify several symbols which include: 1). Living beings symbolize animate things icluding humans, animals and plants which have the meaning of piety, faith, honor, power, loyalty, stength, peace and so on. 2). These objects include types of objects such as bottles, anchors, glasses which have the meaning of being transparent, and easily cracked.

Meanings of symbolism in "Retak Mencari Belah" poetry by Junewal Muchtar : 1). people sitting back and side [Pious, Faith], 2). Tree [strength and tranquility], 3). Bottle [Closed], 4). Anchor [Strength], 5). Glass [Transparent], 6). Centipede [Power], 7). People standing [half], 8). Butterfly [Beauty and prosperity], 9). Spruce [Balance], 10). Index Finger [Directions and directions], 11). Bolts [Strength], 12). [Lighting] lamp, 13). Bee [Strength], 14). Leaf of bamboo shoots [Peace], 15). Mangroves [Life], 16). Cactus [Toughness], 17). Twig [Silence], 18). Aircraft [Speed], 19). Scales [Justice], 20). Ants [Cooperation, Friendship].

\section{Acknowledgements}

Thank you to the Dean of the Faculty of Indonesian Language and Literature for providing the opportunity to carry out service activities.

Thank you to Mrs. Mini who has provided inspiration for further research.

Thank you to friends who have provided encouragement and motivation.

\section{References}

[1] Andiani, Isniani. Simbolisme struktur puisi-puisi karya Suryatati A. Manan. 2013; Vol.1 No.1.

[2] Dibia, I ketut. Apresiasi Bahasa dan Sastra Indonesia. Depok: PT. RajaGrafindo Persada; 2018 
[3] Kosasih, E. Dasar-dasar keterampilan bersastra. Bandung: Yrama Widya; 2012.

[4] Merriam. Webster New World Dictionary \& Thesaurus. New Delhi: IDG Books Of India Pvt Ltd; 1997.

[5] Minderop. Metode Karakteristik Telaah fiksi. Jakarta: Yayasan Obor Indonesia; 2005.

[6] Pradopo, Rachmat. Pengkajian Puisi. Yogyakarta: Universitas Press; 2017.

[7] Pradopo, Rachmat. Beberapa Teori Sastra, Metode Kritik, dan Penerapannya. Yogyakarta: Pustaka Pelajar; 2018.

[8] Ratna, Nyoman Kutha. Teori, Metode dan Teknik Penelitian sastra (dari Stukturalisme, Hingga post Strukturalisme Perspektif Wacana Naratif). Yogyakarta: Pustaka Pelajar; 2015.

[9] Siswanto, Wajyudi. Pengantar Teori Sastra. Jakarta: PT Grasindo; 2008.

[10] Subroto, Edi D. Pengantar Penelitian linguistic Struktural. Surakarta: UNS Press; 1992.

[11] Tim Disdikbud. Kumpulan Puisi Retak Mencari Belah Junewal Muchtar. Tanjungpinang: Quality; 2013.

[12] Waluyo, J Herman. Teori dan Apresiasi Puisi. Jakarta: Erlangga; 1987.

[13] Setiawan, Ichwan. Symbols In Robert Frost's Poems. Malang: Universitas Islam Negeri; 2014. 